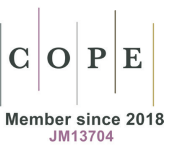

\title{
Slowo wstepne
}

$\mathrm{P}$ rezentowany 105 tom serii wydawniczej „Folia Historica” jest dopełnieniem dwóch wcześniejszych tomów (103 i 104) i zawiera pozostałe artykuły, będące rozszerzonymi wersjami referatów wygłoszonych na III Ogólnopolskiej Konferencji Naukowej z cyklu Oblicza wojny, która odbyła się w dniach 7-8 czerwca 2018 r. w Instytucie Historii Uniwersytetu Łódzkiego. Zamieszczony w niniejszym tomie zbiór 12 artykułów jest rezultatem studiów badawczych historyków zajmujących się problematyką ogólnohistoryczną, ukierunkowanych - zgodnie z tematem przewodnim wspomnianej konferencji - na szeroko rozumianym zagadnieniu Ludzie wojny. O losach wojen decydowało na przestrzeni dziejów wiele czynników, jak np. liczebność armii, jej organizacja, uzbrojenie i wyposażenie, logistyka wojenna oraz stosowana taktyka i strategia. Oprócz nich duży wpływ na przebieg działań wojennych wywierali także poszczególni dowódcy, którzy swoim doświadczeniem i nieszablonowymi posunięciami niejednokrotnie wpływali na ostateczny wynik bitew oraz całych kampanii wojennych. Oczywiście pojęcie ,ludzie wojny” jest rozumiane szeroko i obejmuje - oprócz samych dowódców - także żołnierzy, gdyż bez nich nawet najzdolniejsi wodzowie nie mieliby możliwości odniesienia sukcesu. Dlatego też niezmiernie istotnym zagadnieniem związanym z tematem przewodnim wspomnianej konferencji była także problematyka dotycząca wyszkolenia żołnierzy i ich morale, gdyż elementy te również wpływały na losy bitew i wojen. Autorzy tekstów zamieszczonych w tomie reprezentują polskie ośrodki akademickie oraz placówki muzealne i towarzystwa naukowe: Uniwersytet Jagielloński, Uniwersytet Łódzki, Uniwersytet Mikołaja Kopernika w Toruniu, Uniwersytet Marii Curie-Skłodowskiej w Lublinie, Uniwersytet Warmińsko-Mazurski w Olsztynie, Uniwersytet Humanistyczno-Przyrodniczy im. Jana Długosza w Częstochowie, Muzeum Tradycji Niepodległościowych w Łodzi oraz Instytut Pamięci Narodowej. W zamieszczonych w tomie tekstach autorzy zaprezentowali wyniki swoich najnowszych badań, opartych na poddanych analizie archiwaliach i innych materiałach źródłowych oraz wykorzystanej literaturze przedmiotu. Wśród

${ }^{1}$ Oblicza wojny. Ludzie wojny od średniowiecza po współczesność, red. W. Jarno, J. Kita, „Acta Universitatis Lodziensis. Folia Historica" 2019, nr 103; Oblicza wojny. Ludzie wojny - rycerze i żolnierze, red. T. Grabarczyk, M. Pogońska-Pol, „Acta Universitatis Lodziensis. Folia Historica” 2019, nr 104. 
12 artykułów przeważają teksty poświęcone dowódcom wysokiego szczebla, cztery artykuły zaś odnoszą się do charakterystyki portretów zbiorowych konkretnych grup żołnierzy. Co warto podkreślić, wśród zaprezentowanych sylwetek znajdują się nie tylko postacie, które zapisały się na kartach wielkiej historii, lecz także te mniej znane czy wręcz zapomniane, tzw. bohaterowie drugiego planu. Redaktorzy prezentowanego tomu przyjęli układ chronologiczny przy prezentacji kolejnych tekstów. Problematyka w nich podejmowana rozpoczyna się od epoki średniowiecza, kończy zaś na czasach współczesnych. Przeważają teksty dotyczące problematyki dwudziestowiecznej oraz zagadnień z zakresu dziejów ojczystych.

Pierwszy z zamieszczonych artykułów autorstwa Michala MAdEJA (Uniwersytet Jagielloński) Aethelflaeda - kobieta, która bronita Anglię przed wikinga$m i$ porusza najodleglejszą chronologicznie problematykę, związaną z postacią Aethelflaedy (ok. 870-918), córki Alfreda Wielkiego, króla Wessexu. Artykuł ukazuje jej sylwetkę i dokonania, zwłaszcza na polu walki z zagrażającymi Anglii najazdami wikingów. Dążeniem Aethelflaedy, która niebawem została królową Mercji, była walka z najeźdźcami, której zwieńczeniem miało być ich wyparcie z Wysp Brytyjskich. Nie było to zadanie proste, toteż poświęciła mu całe swe życie. I choć celu ostatecznego nie osiągnęła, to jednak odniosła w tym zakresie wiele sukcesów. Realizację prowadzonej przez nią polityki przerwała jej niespodziewana śmierć w 918 r. Pamięć o jej rządach przetrwała wiele pokoleń, co wyraźnie wskazuje, jak ważną była postacią i do tego wyjątkową, gdyż kobieta sprawująca samodzielne rządy królewskie była rzadkim zjawiskiem w średniowiecznej Europie.

Kolejny tekst, MaŁgorzaty Karkochy (Uniwersytet Łódzki), pt. Postać Tadeusza Kościuszki na wybranych obrazach malarza krakowskiego Michała Stachowicza stanowi ciekawe studium malarstwa historycznego Michała Stachowicza (1768-1825). Wspomniany malarz i rysownik zasłynął jako autor obrazów przedstawiających ważne wydarzenia historyczne w dziejach Polski, choć malował także sceny rodzajowe, obrazy religijne czy portrety. Kompozycje M. Stachowicza upamiętniające ważne postacie i wydarzenia historyczne stanowią istotną część jego dorobku. Do najważniejszych prac z tego zakresu należą obrazy dotyczące insurekcji kościuszkowskiej oraz nieodłącznie z nią związanej postaci Tadeusza Kościuszki, bohatera wojny o niepodległość Stanów Zjednoczonych, wodza wspomnianej insurekcji i jednego z najwybitniejszych dowódców drugiej połowy XVIII w. Autorka na wybranych przykładach (w tym najbardziej znanego dzieła artysty Przysięga Kościuszki na Rynku krakowskim) analizuje, jak postać polskiego bohatera narodowego była przedstawiana w pracach Stachowicza. Oprócz realistycznych scen historycznych krakowski malarz tworzył także kompozycje, w których ukazywał alegoryczną postać Kościuszki, mającą poza znaczeniem dosłownym także umowny sens przenośny. Naczelnik jawi się w nich jako niezłomny obrońca ojczyzny, symbolizujący godność i wolność człowieka. 
Inną wybitną postać zapisaną na kartach historii i od ponad 200 lat fascynującą nie tylko badaczy omawia KAMIL SzADKOwsKi (Uniwersytet Jagielloński) w tekście zatytułowanym Napoleon - wojenne refleksje ze Świętej Heleny wedtug relacji Emmanuela hrabiego de Las Cases. Artykuł ukazuje etap życia Napoleona w trakcie jego pobytu na wyspie Świętej Heleny, znany głównie ze wspomnień nielicznych osób towarzyszących mu w jego ostatnich latach życia. Szczególną rolę pośród tych prac zajmuje Memoriał ze Świętej Heleny pióra Emmanuela hrabiego de Las Cases. Nie była to pierwsza z książek wydanych przez towarzyszy Napoleona na wyspie Świętej Heleny, gdyż wcześniej swe relacje opublikowali m.in. William Warden i Barry Edward O’Meara². Autor artykułu zasadniczą uwagę w swych rozważaniach poświęcił jednak wspomnianemu Memoriałowi, który stał się bestsellerem w dziewiętnastowiecznej Europie. Hrabia de Las Cases najpierw opowiada o sobie, po czym przechodzi do właściwych wspomnień z pobytu na wyspie, gdzie towarzyszył Napoleonowi. Autor Memoriału, obok pamiętnikarskich zapisków, prezentuje także opis wcześniejszych wydarzeń z życia Bonapartego. Relacja jest bardzo szczegółowa, gdyż jej twórca opisuje wypowiedzi i najdrobniejsze szczegóły w zachowaniu cesarza Francuzów, a w zasadzie wówczas już byłego władcy. Opinie wyrażane przez Napoleona na temat bieżącej polityki oraz oceny prowadzonych przez siebie wojen nadają mu - we wspomnieniach E. de Las Casesa - celowo rolę autorytetu dla czytelników, propagując białą legendę napoleońską.

Następne teksty dotyczą już XX w. Tę część tomu otwiera artykuł ALEKSANDRA SMOLIŃSKIEGo (Uniwersytet Mikołaja Kopernika w Toruniu) - Zachodnia Dywizja Strzelecka Armii Czerwonej. Przyczynek do dziejów polskojęzycznych formacji Robotniczo-Chłopskiej Armii Czerwonej w latach 1917-1919. Autor omawia uwarunkowania społeczno-polityczne oraz rzeczywiste powody polityczne przyświecające władzom bolszewickiej Rosji w sprawie zorganizowania polskojęzycznej formacji zbrojnej w ramach Armii Czerwonej, jaką była Zachodnia Dywizja Strzelecka utworzona w październiku 1918 r. W jej składzie znaleźli się Polacy-komuniści służący wcześniej w różnych jednostkach wspomnianej armii. Do przyszłych krasnoarmiejców podejmujących służbę w tej formacji starano się też docierać za pomocą agitacji i propagandy organizowanej przez biura werbunkowe Zachodniej Dywizji Strzeleckiej, mające stać się szpicą rewolucji wśród Polaków. W dalszej części tekstu autor przeprowadził analizę rzeczywistych efektów procesu formowania tego związku taktycznego oraz omówił przyczyny rezygnacji przez władze bolszewickiej Rosji z dalszego istnienia

${ }^{2}$ [W. Warden], Letters written on board His Majesty's ship the Northumberland, and at St. Helena: in which the conduct and conversation of Napoleon Buonaparte, and his suite, during the voyage, and the first months of his residence in that island, are faithfully described and related, by William Warden, $3^{\text {rd }}$ ed., London 1816; B.E. O'M e a ra, Napoléon en exil ou l'écho de Sainte-Hélène, Paris 1822. 
Zachodniej Dywizji Strzeleckiej. Odstąpiono od tego w momencie, gdy władze bolszewickie uznały, że plany wywołania rewolucji w Polsce - wspomaganej przez kadry tej dywizji - stały się nierealne. W czerwcu 1919 r. przeformowano ją w 52 Dywizję Strzelecką Armii Czerwonej, która straciła swój dotychczasowy „polski” charakter.

Kolejny tekst, autorstwa Waldemara Kozyry (Uniwersytet Marii Curie-Skłodowskiej w Lublinie), zatytułowany Generat Władysław Sikorski - minister spraw wewnętrznych Rzeczypospolitej Polskiej (16 grudnia 1922 - 28 maja 1923) ukazuje niezwykle ciekawy i nieco zapomniany fragment $\mathrm{z}$ bogatego życiorysu gen. Władysława Sikorskiego, gdy jako premier polskiego rządu zajmował jednocześnie stanowisko ministra spraw wewnętrznych. Stanowiska te objął w grudniu 1922 r., po zabójstwie pierwszego prezydenta RP Gabriela Narutowicza. Z uwagi na napiętą sytuację wewnętrzną podstawowym zadaniem nowego premiera i ministra spraw wewnętrznych było dążenie do jej uspokojenia. Oba stanowiska dawały gen. W. Sikorskiemu możliwość bezpośredniego oddziaływania na sytuację w kraju, czego wyrazem było m.in. wprowadzenie stanu wyjątkowego oraz aresztowanie najbardziej aktywnych działaczy nacjonalistycznych. Jednak gabinet gen. W. Sikorskiego nie miał stabilnego poparcia żadnej z liczących się wówczas sił politycznych, co było jedną z przyczyn jego szybkiego upadku. Tym niemniej zdążył on przygotować założenia całościowej polskiej polityki wobec mniejszości narodowych, której podstawą była koncepcja asymilacji państwowej. Gabinet gen. W. Sikorskiego upadł w końcu maja 1923 r., kończąc niezwykle ciekawy etap w karierze wojskowo-politycznej tego wybitnego wojskowego i polityka.

Kolejne trzy teksty odnoszą się bezpośrednio do wydarzeń drugiej wojny światowej. Artykuł napisany przez KonRada A. Czernielewskiego (Muzeum Tradycji Niepodległościowych w Łodzi) zatytułowany został Adam Brzechwa-Ajdukiewicz - ostatni dowódca 26 Dywizji Piechoty. Ukazuje on postać jednego z dowódców armii polskiej okresu międzywojennego. Urodzony pod Krakowem A. Brzechwa-Ajdukiewicz służył najpierw w Legionach Józefa Piłsudskiego, a następnie - po kryzysie przysięgowym - w armii austro-węgierskiej. Po odzyskaniu przez Polskę niepodległości podjął służbę w Wojsku Polskim, dochodząc w 1938 r. do stanowiska dowódcy 26 Dywizji Piechoty. Przez pryzmat kariery wojskowej autor omówił posiadane przez niego doświadczenie bojowe, mające zasadniczy wpływ na dowodzenie wspomnianą dywizją w kampanii wrześniowej. Po krótkim zarysie historii tego związku taktycznego autor przeszedł do opisu jego mobilizacji i udziału w wojnie w 1939 r., jak również roli płk. dypl. A. Brzechwy-Ajdukiewicza w prowadzeniu przez podległe mu oddziały działań wojennych. Po kapitulacji znalazł się on w niewoli niemieckiej, a po uwolnieniu z niej w kwietniu 1945 r. przez wojska amerykańskie służył krótko w Polskich Siłach Zbrojnych na Zachodzie. 
Z kolei Andrzej Dubicki (Uniwersytet Łódzki) i TAdeusz Dubicki (Uniwersytet Humanistyczno-Przyrodniczy im. Jana Długosza w Częstochowie) w artykule Misja ppłk. dypl. Jana Kowalewskiego w Portugalii (1940-1944) przedstawili udział płk. Jana Kowalewskiego w tzw. Akcji Kontynentalnej mającej na celu walkę z wrogiem wszystkimi dostępnymi środkami, oprócz działań stricte zbrojnych. Przedsięwzięciu temu - podjętemu przez polskie władze na uchodźstwie - poparcia udzielił rząd brytyjski, wspierając je znacznymi kwotami pieniężnymi. Akcja ta miała w swoim założeniu wyprowadzić z sojuszu z III Rzeszą związane z nią kraje, takie jak Włochy, Rumunia i Węgry. Pułkownik J. Kowalewski - jako były attaché wojskowy RP w Bukareszcie - miał niezbędne doświadczenie w pracy dyplomatycznej oraz szerokie kontakty w Europie Środkowej, zwłaszcza w Rumunii. Autorzy szczegółowo opisali wysiłki podejmowane w ramach tzw. Akcji Kontynentalnej przez kierującego nią J. Kowalewskiego, jak również powody jego odwołania z portugalskiej Lizbony, skąd kierował wspomnianą akcją przez kilka lat. Jego działalność została przerwana decyzją władz brytyjskich w 1944 r., które obawiały się reakcji rządu sowieckiego na próbę utworzenia bloku państw europejskich na bazie antykomunistycznej, a sam J. Kowalewski - wrogo nastawiony do komunizmu - stał się dla Brytyjczyków zbędnym balastem obciążającym ich stosunki z Sowietami.

Tekst Jakuba Parola (Muzeum Tradycji Niepodległościowych w Łodzi) pt. Wizerunek Watera Pelzhausena, komendanta więzienia w Radogoszczu w zeznaniach $i$ wspomnieniach bytych więźniów omawia mało znaną postać Waltera Pelzhausena (1891-1948), zajmującego w latach 1940-1945 stanowisko komendanta więzienia na Radogoszczu w Łodzi. Przeszło ono do historii jako miejsce martyrologii tysięcy ludzi, przetrzymywanych w koszmarnych warunkach i nadzorowanych przez sadystycznych strażników. W relacjach i zeznaniach więźniów W. Pelzhausen uchodził za sadystę, znęcającego się nad osobami przebywającymi w więzieniu, który także osobiście dokonywał egzekucji na osadzonych. Kierował również przeprowadzoną nocą z 17 na 18 stycznia 1945 r. likwidacją więzienia i wymordowaniem w jej trakcie ponad tysiąca osadzonych tu więźniów. Autor - korzystając z licznych relacji i zeznań byłych więźniów - podjął próbę przedstawienia sylwetki komendanta więzienia i rzeczywistej oceny jego sadystycznej natury.

W dalszej części tomu znajduje się artykuł AnNy MarcinKIEWICZ-KaCZMARCZYK (Archiwum Instytutu Pamięci Narodowej w Warszawie) zatytułowany Elżbieta Zawacka (1909-2009) - zastużony żotnierz i aktywna ,feministka", ukazujący życiorys jednej z najciekawszych postaci kobiecych związanych z polską armią okresu międzywojennego. Była jedną z najaktywniejszych propagatorek Przysposobienia Wojskowego Kobiet, pełniąc m.in. funkcję komendantki tej organizacji na Górnym Śląsku. Okres ten miał duży wpływ na kształtowanie jej zainteresowań pedagogicznych, które rozwinęła w późniejszym okresie swego 
życia. We wrześniu 1939 r. czynnie uczestniczyła w walkach, organizując w Katowicach placówki dworcowe dla żołnierzy oraz placówki sanitarne dla ludności cywilnej. Później znalazła się we Lwowie, gdzie brała udział w przygotowaniach obronnych miasta, służąc m.in. w Batalionie Pomocniczej Wojskowej Służby Kobiet. Po kapitulacji Lwowa przybyła do Warszawy. Tu podjęła służbę w Wydziale Łączności Konspiracyjnej Służby Zwycięstwu Polsce, po czym skierowano ją na Górny Śląsk w celu pomocy w tworzeniu tam struktur konspiracyjnej wojskowej służby kobiet. Następnie została kurierem między Komendą Główną Armii Krajowej w Warszawie a Sztabem Naczelnego Wodza w Londynie. Ze stolicy Wielkiej Brytanii powróciła we wrześniu 1943 r. do okupowanego kraju i włączyła się ponownie w działalność konspiracyjną, uczestnicząc m.in. w powstaniu warszawskim. Po zakończeniu drugiej wojny światowej poświęciła się pracy naukowej z zakresu pedagogiki społecznej, pracując na różnych stanowiskach w oświacie, m.in. w Łodzi, Toruniu i Olsztynie, gdzie została aresztowana i skazana na 10 lat więzienia za „współpracę z obcym wywiadem”. Po zwolnieniu z więzienia kontynuowała pracę naukową - uzyskując w 1996 r. tytuł naukowy profesora zwyczajnego. Za swoje zasługi w pracy wojskowej oraz na polu naukowym, pedagogicznym i społecznym otrzymała liczne nagrody i wyróżnienia, w tym m.in. Order Orła Białego oraz tytuł Kustosza Pamięci Narodowej, jak również awans na stopień generała brygady.

Ciekawą problematykę znajdziemy w kolejnym artykule, napisanym przez Haling̨ ŁaCH (Uniwersytet Warmińsko-Mazurski w Olsztynie) pt. Przywracanie $i$ utrwalanie pamięci $w$ spoleczeństwie polskim o żolnierzach formacji granicznych Drugiej Rzeczypospolitej poległych $w$ walkach obronnych z niemieckimi $i$ sowieckimi wojskami we wrześniu 1939 r. Tekst zawiera refleksje w odniesieniu do problemu utrwalania pamięci społecznej o żołnierzach polskich formacji granicznych z czasów Drugiej Rzeczypospolitej. Pełnili oni nie tylko trudną służbę graniczą, strzegąc polskich granic, lecz także bohatersko walczyli we wrześniu 1939 r. zarówno z najeźdźcą niemieckim, jak i sowieckim. Po 1945 r. komunistyczne władze powojennej Polski dokładały wielu starań, aby zatrzeć pamięć o heroizmie poległych żołnierzy formacji granicznych, którzy niemal całkowicie zniknęli z kart ówczesnej polskiej historiografii. Należną im pamięć zaczęto przywracać dopiero po transformacji w 1989 r. W artykule autorka ukazała problem przywracania i utrwalania w społeczeństwie pamięci o żołnierzach Korpusu Ochrony Pogranicza i Straży Granicznej poległych w kampanii polskiej 1939 r., których pamięć i chlubne tradycje kultywuje współczesna Straż Graniczna.

Przedostatni w tomie tekst, autorstwa Magdaleny PogońsKiej-Pol (Uniwersytet Lódzki), Fauzi al-Kawukdżi $i$ Abd al-Kadir al-Husajni $w$ walce o niepodległość Palestyny omawia działania podejmowane przez Fauziego al-Kawukdżiego i Abd al-Kadir al-Husajniego w czasie tzw. wojny domowej 
w brytyjskim mandacie Palestyny w 1948 r. Autorka szczegółowo opisała uwarunkowania panujące wówczas na Bliskim Wschodzie, zwłaszcza w odniesieniu do Palestyny, o której niepodległość walczyli obaj bohaterzy niniejszego tekstu: Fauzi al-Kawukdżi oraz Abd al-Kadir al-Husajni. Pierwszy z nich stał na czele Arabskiej Armii Wyzwolenia, drugi zaś dowodził Armią Świętej Wojny. Obaj chcieli nie dopuścić do wejścia w życie rezolucji Organizacji Narodów Zjednoczonych dotyczącej podziału Palestyny na dwa państwa. To właśnie oni - na czele sił nieregularnych - wzięli na siebie cieżar walki i borykali się z licznymi przeciwnościami. Nie współpracowali ze sobą, lecz walczyli przeciwko Żydom przybyłym do Palestyny w imię jednej sprawy, jaką było dążenie do powstania niezależnego państwa arabskiego.

Tom zamyka artykuł KATARZYNY DeRlatKi (Uniwersytet Łódzki) zatytułowany Ludzie wojny w medialnym obrazie świata ukazujący problematykę ,ludzi wojny" w innym ujęciu. Zazwyczaj ograniczamy ją do tych, którzy wojny wywołują, prowadzą i walczą w nich jako dowódcy i żołnierze. Wojna może mieć jednak nieco inny wymiar, bezkrwawy, bez zniszczeń, ale widoczny w skutkach i w przyszłym rezultacie wojny. W szerszym ujęciu ,ludzie wojny” to także w coraz większym stopniu mimowolne ofiary cywilne oraz całe społeczeństwa, które dezinformowane i manipulowane mogą wpływać na przebieg konfliktów we współczesnym świecie w interesie strony atakującej informacyjnie. Omówione w artykule skutki konfliktów dotyczą w głównej mierze wojny nowej generacji - zwanej wojną informacyjną, która choć bezkrwawa, może być równie niszcząca i destabilizacyjna, jak dawne wojny klasyczne.

Zamieszczone w tomie artykuły kończą publikację złożonych do druku materiałów będących pokłosiem III Ogólnopolskiej Konferencji Naukowej z cyklu Oblicza wojny, z podtytułem Ludzie wojny organizowanych od kilku lat przez łódzkie środowisko naukowe. Poszczególne teksty ukazują szerokie spektrum poglądów na dzieje wojskowe i społeczne, obejmując kręgiem zainteresowań badawczych problematykę tematu wiodącego konferencji, ujętego pod wieloaspektowo rozumianym pojęciem ,ludzie wojny”. Autorami artykułów są specjaliści zajmujący się szeroko rozumianą problematyką wojskową, którzy wykorzystali szereg nowych źródeł bądź dokonali ich nowego odczytania pod kątem wspomnianego tematu wiodącego. Różnorodność poruszanej problematyki stanowi z pewnością poważny atut tomu i wyraźnie wskazuje na to, że losy dowódców (zarówno tych znanych, jak i tych nieco zapomnianych lub drugoplanowych) oraz podległych im żołnierzy w ujęciu tzw. portretów zbiorowych cieszą się dużym zainteresowaniem wielu badaczy, którzy opisują ową tematykę na różne sposoby, zwracając zarazem uwagę na różnorodne jej aspekty. Artykuły poruszają zagadnienia dotychczas mało znane lub słabo przebadane, dzięki czemu są interesującymi przyczynkami badawczymi, poszerzającymi wiedzę w wybranych 
przykładach szeroko rozumianej problematyki dowódców i ich podkomendnych, co stanowi o wartości naukowo-poznawczej publikowanych tu tekstów. Z pewnością nie wyczerpują one poruszanych zagadnień, lecz stanowią zarazem impuls do dalszych pogłębionych badań. Redaktorzy tomu wyrażają przekonanie, że zainteresowani historią wojskowości znajdą w nim dla siebie ciekawe i oryginalne materiały.

WITOLD JARNO

(UNIWERSYTET ŁÓDZKI)*

iD https://orcid.org/0000-0002-5845-6057

JAROSŁAW KITA

(UNIWERSYTET ŁÓDZKI)**

(iD) https://orcid.org/0000-0002-8374-2848

* Wydział Filozoficzno-Historyczny, Instytut Historii, Katedra Historii Polski i Świata po 1945 roku, e-mail: wjarnolodz@op.pl

** Wydział Filozoficzno-Historyczny, Instytut Historii, Katedra Historii Polski XIX wieku, e-mail: jaroslawkita@poczta.onet.pl 